\title{
Weight gain and morphometric growth of genetically improved tambaqui (Colossoma macropomum) ${ }^{1}$
}

\author{
Ganho de peso e crescimento morfométrico do tambaqui \\ (Colossoma macropomum) melhorado geneticamente ${ }^{1}$
}

\author{
Rebeca Marcos 2 ; Jayme Aparecido Povh ${ }^{3 *}$; Darci Carlos Fornari ${ }^{4}$; \\ Carlos Antonio Lopes de Oliveira ${ }^{5}$; Ricardo Pereira Ribeiro ${ }^{5}$; \\ Nelson Mauricio Lopera-Barrero ${ }^{6}$; Ruy Alberto Caetano Corrêa Filho ${ }^{3}$; \\ Janessa Sampaio de Abreu ${ }^{7}$, Pâmela Juliana Furlan Murari ${ }^{8}$
}

\begin{abstract}
Weight gain and morphometric growth of the genetically improved tambaqui (Colossoma macropomum) are evaluated. Current assay was carried out on the Fish Farm Experimental Station of the Federal University of Mato Grosso, in the municipality of Santo Antonio de Leverger - MT Brazil. Seven fish families from the breeding program and a control group (not genetically improved) were evaluated. All animals were individually identified with a transmitter-responder label (transponder). Weight gain, overall and standard length, head size, height, width and body perimeter were measured. A completely randomized design was used and comparisons among families and the control group were carried out by Dunnett test at 5\% significance level. The genetically improved fish families showed a $14.8 \%$ higher weight gain when compared to that of control group. Five out of seven families showed greater weight gain when compared to control group, with the best family exhibiting a $24.8 \%$ higher rate. Four families had higher growth in all evaluated morphometric characteristics when compared to control group. Only one family did not differ in any of the evaluated characteristics with regard to the control group.
\end{abstract}

Key words: Genetic improvement of fish. Fish of the Amazon basin. Genetic selection.

\section{Resumo}

Objetivou-se avaliar o ganho de peso e o crescimento morfométrico do tambaqui (Colossoma macropomum) melhorado geneticamente. $\mathrm{O}$ trabalho foi realizado na Estação Experimental de Piscicultura da Universidade Federal de Mato Grosso, localizada no município de Santo Antônio de Leverger - MT, Brasil. Foram avaliadas sete famílias oriundas do programa de melhoramento genético

${ }_{1}^{1}$ Parte da Dissertação de Mestrado do primeiro autor.

2 Discente do Curso de Doutorado do Programa de Pós-Graduação em Ciência Animal, Universidade Federal de Mato Grosso do Sul, UFMS, Campo Grande, MS, Brasil. E-mail: rebeca.marcos@yahoo.com.br

3 Profs. Drs., UFMS, Campo Grande, MS, Brasil. E-mail: jayme.peixegen@gmail.com; ruy.filho@ufms.br

${ }^{4}$ Prof. Dr., Curso de Agronegócio, Faculdades La Salle, Lucas do Rio Verde, MT, Brasil. E-mail: darci.peixegen@gmail.com

5 Profs. Drs., Dept ${ }^{\circ}$ de Zootecnia, Programa de Pós-Graduação em Zootecnia, Universidade Estadual de Maringá, UEM, Maringá, PR, Brasil. E-mail: caloliveira@uem.br; rpribeiro@uem.br

${ }^{6}$ Prof. Dr., Dept ${ }^{\circ}$ de Zootecnia, Programa de Pós-Graduação em Ciência Animal, Universidade Estadual de Londrina, UEL, Londrina, PR, Brasil. E-mail: nmlopera@uel.br

7 Prof ${ }^{a}$ Dra $^{\mathrm{a}}$, Universidade Federal de Mato Grosso, UFMT, Cuiabá, MT, Brasil. Email: janessabreu@yahoo.com.br

${ }^{8}$ Discente do Curso de Doutorado do Programa de Pós-Graduação em Ciência Animal, UEL, Londrina, PR, Brasil. E-mail: pamela. furlan@outlook.com

* Author for correspondence 
e um grupo controle (não melhorado geneticamente). Todos os animais foram individualizados com transponder. Foram mensurados o ganho de peso, comprimento total e padrão, tamanho de cabeça, altura, largura e perímetro do corpo. Utilizou-se delineamento inteiramente casualizado e as comparações entre as famílias e o grupo controle foram realizadas pelo teste de Dunnett com 5\% de significância. As famílias melhoradas geneticamente apresentaram ganho de peso $14,8 \%$ superior ao grupo controle. Cinco das sete famílias avaliadas apresentaram maior ganho de peso em relação ao grupo controle, sendo que a melhor família foi superior em $24,8 \%$. Quatro famílias apresentaram maior crescimento em todas as características morfométricas avaliadas em relação ao controle. Apenas uma família não diferiu em nenhuma das características avaliadas em relação ao grupo controle.

Palavras-chave: Melhoramento genético de peixes. Peixe da bacia amazônica. Seleção genética.

\section{Introduction}

Colossoma macropomum (Cuvier 1818), popularly known as "tambaqui" in Brazil, belongs to the Characiform order, Characidae family and Myleinae sub-family. It is an autochthonous fish of the Amazon basin, widely distributed in the tropical regions of South America and Central Amazon (ARAÚJO-LIMA; GOULDING, 1997), considered the second largest scale fish of the Solimões and Amazon rivers. It may reach up to $100 \mathrm{~cm}$ long and weigh $30 \mathrm{~kg}$ in its natural environment (NAKATANI et al., 2001).

The Ministry of Fisheries and Aquaculture (MPA) and the Brazilian Institute of Geography and Statistics (IBGE) considered the tambaqui one of the most important fish species in Brazilian economy in 2011. It was produced in 25 of the 26 Brazilian states and ranked second in the production of aquatic organisms (BRASIL, 2013; IBGE, 2013), due to several favorable zootechnical characteristics and high commercial value (ARAÚJO-LIMA; GOMES, 2010; LOPERA-BARRERO et al., 2012).

The 2012/2013 tambaqui production reached 111,084 tons (BRASIL, 2013) and when calculated with other round fish such as the pacu (Piaractus mesopotamicus), pirapitinga (Piaractus brachypomus) and their hybrids (tambacu, tambatinga and patinga), production amounted to 228,064 tons (BRASIL, 2013).

The genetic improvement program of the species Colossoma macropomum (tambaqui) and Pseudoplatystoma reticulatum (cachara) was implemented in the north-western state of Mato Grosso late in 2008, featuring the first breeding program for native fish in Brazil. The first selected generation of tambaqui for weight gain (G1) was obtained at the end of 2011 and early 2012, with positive effects on growth pattern and weight gain (OLIVEIRA et al., 2012; MELLO et al., 2015).

Current study evaluated weight gain and the morphometric growth of genetically improved tambaquis (Colossoma macropomum).

\section{Material and Methods}

The experiment was carried out on the Experimental Farm of the Federal University of Mato Grosso, in the municipality of Santo Antonio do Leverger, MT, Brazil (15 51 ' $56^{\prime}$ ' S; $56^{\circ} 04$ ' 36" W). Nine biometric parameters were performed every 30 days during 254 days (between September 2012 and May 2013). Current assay started when fish were 217 days old and all fish were evaluated for weight gain and morphometric measures: total and standard length, size of head, height, width and body perimeter, totaling 2.849 items.

Tambaqui families for the generation of the first genetic selection for weight gain (G1) were obtained in January 2012 from the satellite center for fish breeding in the northern region of the state of Mato Grosso (Delicious Fish), Brazil (12 $51^{\prime}$ $56.40 " \mathrm{~S} ; 55^{\circ} 50$ ' 03.30 " W). The progeny was generated after three years of formation of the base 
population, when the fish reached sexual maturity (animals from the initial breeding stock program of native fish in Brazil). The seven tambaqui families assessed derived from the reproduction of seven broodstocks and seven matrixes which were selected for their incremented genetic potential for daily weight gain. Further, $5.50 \mathrm{mg}$ of carp pituitary extract $/ \mathrm{kg}$ live weight were employed in two applications for females and $2.50 \mathrm{mg}$ of carp pituitary extract $/ \mathrm{kg}$ live weight were applied in a single application for males.

After gamete extrusion and fertilization, the eggs were incubated in the proportion of $1.00 \mathrm{~g} /$ liter of water. After absorption of the vitelline sac, the postlarvae were placed in $500 \mathrm{~L}$ boxes and fed on meal ( $36 \%$ of crude protein) and zooplankton. Thirty-dayold juveniles were placed in $3.00 \mathrm{~m}^{3}$ hapas till they were $12.00 \mathrm{~cm}$ long (the size required for inserting the microchip) and received the same meal as in the previous phase. Juveniles were later transported to the experimental units of the Experimental Farm of the Universidade Federal de Mato Grosso.

Further, 388 young fish were used (average weight $65.38 \pm 20.00 \mathrm{~g}$ and total length $15.00 \pm 1.25$ $\mathrm{cm}): 252$ fish were retrieved from the seven families of the breeding program and 136 fish lacked any genetic selection, forming the control group (animals purchased on the market). Weighting over $20.00 \mathrm{~g}$, all fish were individually identified by transponder implanted on the dorsal region.

The tambaqui genetic groups (genetically improved and control group) were placed in two 800 $\mathrm{m}^{2}$ earth tanks. The final biomass $0.485 \mathrm{fish} / \mathrm{m}^{2}$ was taken into account. There was a partial replacement of water during the experiment (averaging 5\%). Fish were fed twice a day (09:00 a.m. and 04:00 p.m.) on extruded meal containing $32 \%$ protein. The amount of daily feed was adjusted monthly according to biometrics.

During the experiment, water quality was monitored weekly (in the morning). The parameters temperature, dissolved oxygen, $\mathrm{pH}$, total alkalinity, total ammonia and non-ionized ammonia were evaluated.

The experiment started after a 15-day acclimation period of the fish in earth tanks. All fish were evaluated monthly for total weight/day and for morphometric characteristics of total and standard length, head size, height, width and body circumference (Figure 1). Fished fasted for 12 hours prior to biometrical evaluation. They were then anesthetized in an eugenol solution $(50 \mathrm{mg} / \mathrm{L})$ following methodology by Inoue et al. (2011) in a totally.

Figure 1. Measured morphometric characteristics $(\mathrm{cm})$ of tambaqui (Colossoma macropomum). Were measured head length $(\mathrm{HL})(\mathrm{cm})$, height $(\mathrm{BH})(\mathrm{cm})$, width $(\mathrm{BW})$ $(\mathrm{cm})$, perimeter $(\mathrm{PE})(\mathrm{cm})$, standard length $(\mathrm{SL})$ and total length $(\mathrm{TL})(\mathrm{cm})$ of the body during 264 days of observation.

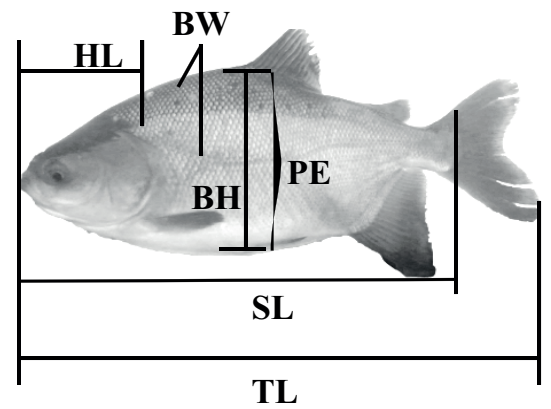

Data retrieved from nine monthly biometric evaluations of the seven tambaqui families from the breeding program and from the control group were assessed with SAS statistical software. Treatments (families and control group) were compared by Dunnett Test at 5\% significance, comparing family averages with the control group (CARDELLINO; SIEWERDT, 1992).

\section{Results and Discussion}

During the experiment, water quality averages were temperature $\left(30.25 \pm 1.39{ }^{\circ} \mathrm{C}\right)$, dissolved oxygen $\left(5.05 \pm 2.14 \mathrm{mg} \mathrm{L}^{-1}\right), \mathrm{pH}(6.89 \pm 0.91)$, total 
alkalinity $\left(66.42 \pm 27.42 \mathrm{mg} \mathrm{L}^{-1}\right)$, total ammonia $\left(0.07 \pm 0.05 \mathrm{mg} \mathrm{L}^{-1}\right)$ and non-ionized ammonia $\left(0.01 \pm 0.01 \mathrm{mg} \mathrm{L}^{-1}\right)$. There was no significant difference among the experimental units and averages complied with the recommended range for the production of tropical fish, such as the tambaqui (BOYD, 1992; SIPAÚBA-TAVARES, 1995; ARIDE et al., 2006; BALDISSEROTTO; RADÜNZ NETO, 2010).
Families A, B, D, E, and $\mathrm{G}$ showed greater weight gain when compared to the control group (not genetically improved fish) during 264 days of observation. Whereas the biggest difference was observed for family A $(480.00 \pm 10.23 \mathrm{~g})$ and the smallest difference was reported for family $\mathrm{G}(380.00 \pm 56.42 \mathrm{~g})$, families $\mathrm{C}$ and $\mathrm{F}$ showed no significant difference $(p>0.05)$ in weight gain when compared to control group (Table 1).

Table 1. Weight gain and measured morphometric characteristics of genetically selected tambaqui (Colossoma macropomum) for weight gain during 264 days of observation.

\begin{tabular}{lcccccccc}
\hline \multicolumn{7}{c}{ Weight gain parameters and morphometric characteristics } \\
\hline & $\begin{array}{c}\text { TWG } \\
\mathbf{( g )}\end{array}$ & $\begin{array}{c}\text { TL } \\
\mathbf{( c m}\end{array}$ & $\begin{array}{c}\text { SL } \\
\mathbf{( c m})\end{array}$ & $\begin{array}{c}\text { HS } \\
\mathbf{( c m})\end{array}$ & $\begin{array}{c}\text { BH } \\
\mathbf{( c m})\end{array}$ & $\begin{array}{c}\text { BW } \\
\mathbf{( c m})\end{array}$ & $\begin{array}{c}\text { BP } \\
(\mathbf{c m})\end{array}$ & $\begin{array}{c}\text { DWG } \\
(\mathbf{g})\end{array}$ \\
\hline Control & $1465.59 \pm 259.35$ & $42.33 \pm 2.01$ & $34.38 \pm 1.71$ & $10.61 \pm 0.51$ & $17.22 \pm 1.59$ & $6.19 \pm 0.47$ & $36.33 \pm 4.00$ & $6.80 \pm 1.27$ \\
Fam. A & $1947.83 \pm 249.12^{*}$ & $44.85 \pm 1.81^{*}$ & $36.62 \pm 1.76^{*}$ & $11.40 \pm 0.65^{*}$ & $19.79 \pm 1.12^{*}$ & $6.90 \pm 0.40^{*}$ & $40.76 \pm 1.78^{*}$ & $9.06 \pm 1.15^{*}$ \\
Fam. B & $1670.18 \pm 313.32^{*}$ & $42.77 \pm 2.46$ & $35.06 \pm 1.98$ & $10.97 \pm 0.64^{*}$ & $18.47 \pm 1.55^{*}$ & $6.57 \pm 0.51^{*}$ & $38.89 \pm 2.46^{*}$ & $7.84 \pm 1.46^{*}$ \\
Fam. C & $1324.01 \pm 319.28$ & $40.38 \pm 2.75^{*}$ & $33.20 \pm 2.43^{*}$ & $10.26 \pm 0.58^{*}$ & $16.31 \pm 1.63^{*}$ & $6.05 \pm 0.69$ & $35.76 \pm 2.96$ & $6.41 \pm 1.35$ \\
Fam. D & $1736.91 \pm 225.23^{*}$ & $43.63 \pm 1.75^{*}$ & $35.67 \pm 1.58^{*}$ & $11.06 \pm 0.46^{*}$ & $18.68 \pm 1.49^{*}$ & $6.66 \pm 0.40^{*}$ & $39.60 \pm 1.78^{*}$ & $8.13 \pm 0.94^{*}$ \\
Fam. E & $1681.02 \pm 164.44^{*}$ & $43.74 \pm 2.16^{*}$ & $35.77 \pm 1.23^{*}$ & $11.11 \pm 0.47^{*}$ & $18.39 \pm 0.80^{*}$ & $6.57 \pm 0.41^{*}$ & $38.37 \pm 1.20^{*}$ & $7.86 \pm 0.77^{*}$ \\
Fam. F & $1346.25 \pm 139.14$ & $41.87 \pm 1.20$ & $34.23 \pm 1.06$ & $10.44 \pm 0.47$ & $16.77 \pm 1.07$ & $6.01 \pm 0.22$ & $35.81 \pm 1.27$ & $6.29 \pm 0.70$ \\
Fam. G & $1854.79 \pm 315.77^{*}$ & $44.50 \pm 1.88^{*}$ & $36.47 \pm 1.65^{*}$ & $11.34 \pm 0.60^{*}$ & $19.64 \pm 1.09^{*}$ & $6.70 \pm 0.47^{*}$ & $40.56 \pm 1.83^{*}$ & $8.65 \pm 1.43 *$ \\
\hline
\end{tabular}

TWG - total weight gain; TL - total length; SL - standard length; HS - head size; BH - body height; BW - body width; BP - Body perimeter; DWG - daily weight gain; Fam. - family.

Means followed by an asterisk in the same column differ statistically from control group at $5 \%$ probability by Dunnett test.

When all the families in the first tambaqui selection generation were taken into account, results indicated a $14.8 \%$ higher weight gain when compared to that of the control group. However, several families showed much higher weight gain: families A and G had respectively $24.8 \%$ and $21.0 \%$ higher weight gain. Consequently, the first tambaqui selection generation for weight gain demonstrated that weight gain for selection was improved due to the additive genetic values (heritability) derived directly from parents.

Genetic gain ranged between 12.0 and $17.0 \%$ for the generation growth rate in a GIFT strain Nile tilapia (Oreochromis niloticus) breeding program in the Philippines during five generations of genetic selection for weight gain (EKNATH; ACOSTA, 1998; EKNATH et al., 1998; GUPTA; ACOSTA, 2004; LI et al., 2006). Gjedrem (2000) reported estimates of genetic selection responses to weight gain for the rainbow trout (Oncorhynchus mykiss) and the channel catfish (Ictalurus punctatus) with rates 13.0 and $20.0 \%$, respectively. Current assay with the tambaqui revealed that the growth pattern between the groups under analysis during 264 days was different since the genetically improved families had a $14.50 \%$ higher weight gain than that of control. Positive variations for weight gain and daily growth rate, underscoring A, B, D, E and $G$ families, were due to the genetic selection of male and female progenies. The same high growth 
pattern has been registered for genetically improved families with regard to the morphometric measures evaluated.

Comparing different strains of the Nile Tilapia, Massago et al. (2010) reported that the genetically improved GIFT and Supreme strains showed greater weight gain over the not genetically improved Bouaké and Chitralada strains, with rates that reached a $34.8 \%$ difference between the most contrasting strains. The above highlights the importance of genetic improvement to increase productivity.

Total and standard length were higher for A, D, E and $\mathrm{G}$ families when compared to those of the control group $(p<0.05)$. Families $B$ and $F$ showed similar results, whilst family $\mathrm{C}$ revealed a significantly lower rate $(4.0 \%)$ when compared to control group for the two factors (Table 1). The growth of genetically improved tambaquis was proportional to weight gain and demonstrated a statistically significant difference when compared to the control group, except for family B. Although the latter had a greater weight gain, there was no growth difference when compared to control (Table 1).

Families A, B, D, E and G showed a more significant growth in the size of the head when compared to control group, with no significant difference for family $\mathrm{C}$ (Table 1). Body weight affected directly a larger head size. This feature is undesirable since it provides smaller carcass yield (REIDEL et al., 2004; BOMBARDELLI et al., 2005; ADAMES et al., 2014). In fact, Mello et al. (2015) observed that there were differences in the growth pattern of the size of the head in tambaquis, or rather, females had a higher growth rate (albeit slow) when compared to males. However, the authors continued their assay till the sexual maturity of the tambaquis (three years), whereas fish in current assay were assessed in less than half that time (481 days) and without sexual differentiation, which impairs any comparison.

The morphometric features related to body height, width and perimeter were significantly different $(p<0.05)$, with highest growth rate in families A, B, D, E and G; families C and F were similar to control group, except for height in family $\mathrm{C}$, which was lower than that in the control group (Table 1). Results demonstrate that the growth of these morphological characteristics for tambaqui was directly proportional to weight gain, corroborated by similar results reported by Boscolo et al. (2001) for the Nile tilapia.

Daily weight gain (Figure 2a) between genetically selected families and control group followed the same trend of total weight gain (Figure 2b) for families A, B, D, E and G. Daily and total weight gain were respectively higher than $7.50 \mathrm{~g} /$ day and $1.500 \mathrm{~g}$, respectively.

Arbeláez-Rojas et al. (2002) and Izel and Melo (2004) reported lower daily weight gain rates for the tambaqui, or rather, there was a gain of up to $4.5 \mathrm{~g}$ /day after 170 days and $1.69 \mathrm{~g} /$ day after 240 days, respectively. Breeding program families registered gains over $29.0 \%$ when compared to those in current assay, and in less time, emphasizing the importance of breeding program for tambaqui. Mello et al. (2015) reported higher growth rates than those given by these authors and rates close to those in current assay, featuring growth rates at $8.66 \mathrm{~g} /$ day and $9.34 \mathrm{~g} /$ day, respectively for male and female tambaquis. 
Figure 2 Values of (2a) daily weight gain $(\mathrm{g} / \mathrm{d})$ and $(2 \mathrm{~b})$ total weight $(\mathrm{g})$ among the genetically improved tambaqui families (Colossoma macropomum) for weight gain and the control group during 264 days of observation.

$\longrightarrow$ Daily Weight Gain (g/dia) $\quad 2 a$

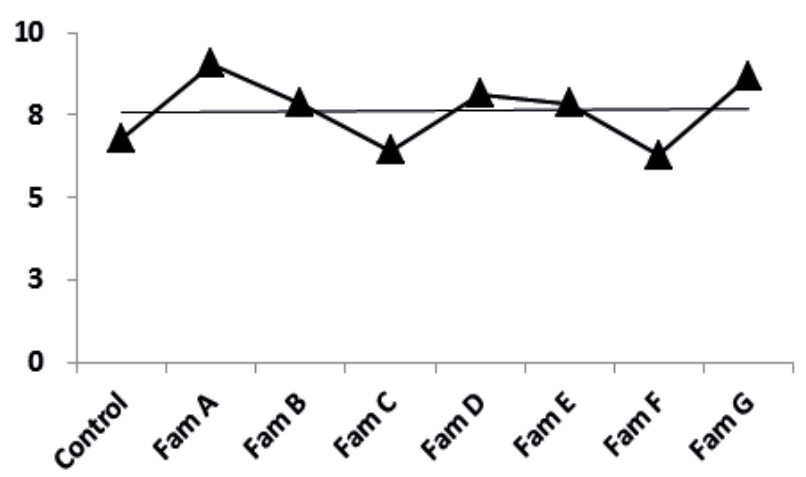

\section{Conclusions}

When all the families in the first generation of tambaqui selection are taken into account, results showed a weight gain over $14.8 \%$ when compared to control group (non-genetically improved).

Further, there was a greater final and daily weight gain of morphometric characteristics in five families (A, B, D, E, and G) of genetically improved tambaqui when compared to that in the control group.

\section{Acknowledgements}

The authors would like to thank FAPEMAT and CNPq for funding. Thanks are also due to UFMT and Delicious Fish for their collaboration.

\section{References}

ADAMES, M. S.; KRAUSE, R. A.; DAMASCENO, D. Z.; PIANA, P. A.; OLIVEIRA, J. D. S.; BOMBARDELLI, R. A. Características morfométricas, rendimentos no processamento e composição centesimal da carne do barbado. Boletim do Instituto de Pesca, São Paulo, v. 40, n. 2, p. 251-260, 2014. Disponível em: <ftp://ftp.sp.gov. br/ftppesca/40_2-251-260.pdf>. Acesso em: 30 out. 2014.

ARBELÁEZ-ROJAS, G. A.; FRACALOSSI, D. M.; FIM, J. D. I. Composição corporal de tambaqui, 2b

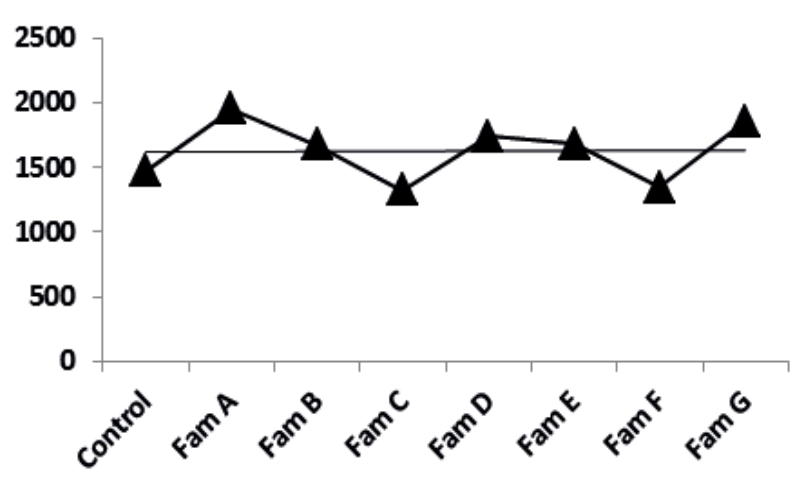

Colossoma macropomum, e Matrinxã, Brycon cephalus, em sistemas de cultivo intensivo, em igarapé, e semiintensivo, em viveiros. Revista Brasileira de Zootecnia, Viçosa, MG, v. 31, n. 3, p. 1059-1069, 2002.

ARAÚJO-LIMA, C.A.R. M.; GOMES, L. de C. Tambaqui (Colossoma macropomum). In: BALDISSEROTTO, B.; GOMES, L. C. Espécies nativas para piscicultura no Brasil. 2. ed. rev. e ampl. Santa Maria: Editora UFSM, 2010. p. 301-333.

ARAUJO-LIMA, C. A. R. M.; GOULDING, M. So fruitful fish: ecology, conservation, and aquaculture of the Amazon's Tambaqui. New York: Columbia University Press, $1997.157 \mathrm{p}$.

ARIDE, P. H. R.; ROUBACH, R.; NOZAWA, S. R.; VAL, A. L. Tambaqui growth and survival when exposed to different photoperiods. Acta Amazônica, Manaus, v. 36, n. 3, p. 381-384, 2006.

BALDISSEROTTO, B.; RADÜNZ NETO, J. Jundiá (Rhamdia sp). In: BALDISSEROTTO, B.; GOMES, L. C. (Ed.). Espécies nativas para piscicultura no Brasil. Santa Maria: UFSM, 2010. p. 301-333.

BOMBARDELLI, R. A.; SYPERRECK, M. A.; SANCHES, E. A. Situação atual e perspectivas para o consumo, processamento e agregação de valor ao pescado. Ciências Veterinárias e Zoologia, Umuarama, v. 8, n. 2, p. 181-195, 2005.

BOSCOLO, W. R.; HAYASHI, C.; SOARES, C. M.; FURUYA, W. M.; MEURER, F. Desempenho e características de carcaça de machos revertidos de tilápias do Nilo (Oreochromis niloticus), linhagens tailandesa e comum, nas fases inicial e de crescimento. Revista Brasileira de Zootecnia, Viçosa, MG, v. 30, n. 5, p. 1391-1396, 2001. 
BRASIL. Ministério da Pesca e Aquicultura - MPA. Boletim estatístico da pesca e aquicultura 2011. Brasília: Ministério da Pesca e Aquicultura, 2013.60 p. Disponível em: <http://www.mpa.gov.br>. Acesso em: 26 out. 2014.

BOYD, C. Water quality management for ponds fish culture in developments in aquaculture and fisheries. Science. $9^{\text {th }}$ ed. New York: Elsevier, 1992. 183 p.

CARDELlinO, R. A.; SIEWERDT, F. Utilização correta e incorreta dos testes de comparação de médias. Revista Brasileira de Zootecnia, Viçosa, MG, v. 21, n. 6, p. 985-995, 1992.

EKNATH, A. E.; DEY, M. M.; RYE, M.; GJERDE, B.; ABELLA, T. A.; SEVILLEJA, R., TAYAMEN, M. M.; REYES, R. A.; BENTSEN, H. B. Selective breeding of Nile tilapia for Asia. In: WORLD CONGRESS ON GENETICS APPLIED TO LIVESTOCK PRODUCTION, 6., 1998, Armidale. Proceedings... Armidale: University of New England, 1998. CD-ROM.

EKNATH, A. E.; ACOSTA, B. O. Genetic improvement of farmed tilapias (GIFT) project. Final Report. March 1988 to december 1997. Makati: International Center for Living Aquatic Resources Management, 1998. v. 2, Part 1.

GJEDREM, T. Genetic improvement of cold-water fish species. Aquaculture Research, Oxford, v. 31, n. 1, p. 2533, 2000.

GUPTA, M. V.; ACOSTA, B. O. From drawing board to dining table: the success story of the GIFT project. Naga: World Fish Center Quarterly, 2004. v. 27, 70 p.

INOUE, L.; BOIJINK, C. L.; RIBEIRO, P. T.; SILVA, A. M. D. da; AFFONSO, E. G. Avaliação de respostas metabólicas do tambaqui exposto ao eugenol em banhos anestésicos. Acta Amazônica, Manaus, v. 41, n. 2, p. 327332, 2011.

INSTITUTO BRASILEIRO DE GEOGRAFIA E ESTATÍSTICA - IBGE. Produção Pecuária Municipal. Rio de Janeiro: IBGE, 2013. v. 41, p. 1-108.

IZEL, A. C. U.; MELO, L. A. S. Criação de tambaqui (Colossoma macropomum) em tanques escavados no Estado do Amazonas. Manaus: Embrapa Amazônia Ocidental, 2004. 20 p. (Embrapa Amazônia Ocidental. Documentos, 32).
LI, S. F.; HE, X. J.; HU, G. C.; CAI, W. Q.; DENG, X. W.; ZHOU, P. Y. Improving growth performance and caudal fin stripe pattern in selected F6-F8 generations of GIFT Nile tilapia (Oreochromis niloticus L.) using mass selection. Aquaculture Research, Oxford, v. 37, n. 12, p. 1165-1171, 2006.

LOPERA-BARRERO, N. M.; RIBEIRO, R. P.; POVH, J. A.; VARGAS-MENDEZ, L. D.; POVEDA-PARRA, A. R. Produção de organismos aquáticos: uma visão geral no Brasil e no mundo. Guaíba: Agrolivros, 2012. 720 p.

MASSAGO, H.; CASTAGNOLLI, N.; MALHEIROS, E. B.; KOBERSTEIN, T. C. R. D.; SANTOS, M. A. dos; RIBEIRO, R. P. Crescimento de quatro linhagens de tilápia Oreochromis niloticus. Revista Acadêmica: Ciências Agrárias e Ambientais, Curitiba, v. 8, n. 4, p. 397-403, 2010.

MELLO, F. de; OLIVEIRA, C. A. L.; RIBEIRO, R. P.; RESENDE, E. K.; POVH, J. A.; FORNARI, D. C.; BARRETO, R. V.; MCMANUS, C.; STREIT JÚNIOR, D. Growth curve by Gompertz nonlinear regression model in female and males in tambaqui (Colossoma macropomum). Anais da Academia Brasileira de Ciências, Rio de Janeiro, v. 87, n. 4, p. 2309-2315, 2015.

NAKATANI, K.; AGOSTINHO, A.; BAUMGARTNER, G.; BIALETZKI, A.; SANCHES, P.; MAKRAKIS, M.; PAVANELLI, C. Ovos e larvas de peixes de água doce: desenvolvimento e manual de identificação. Maringá: EDUEM, 2001. 378 p.

OLIVEIRA, C. A.; RIBEIRO, R. P.; STREIT JÚNIOR, D. P.; POVH, J. A.; RESENDE, E. K. Breedingfish, a reality for Brazilian fish farming $=$ melhoramento genético de peixes, uma realidade para piscicultura Brasileira. Revista Panorama da Aquicultura, Rio de Janeiro, v. 130, n. 247, p. 38-47, 2012.

REIDEL, A.; OLIVEIRA, L. G.; PIANA, P. A.; LEMAINSKI, D.; BOMBARDELLI, R. A.; BOSCOLO, W. R. Avaliação do rendimento e características morfométricas do curimbatá Prochilodus lineatus (Valenciennes, 1836) e do piavuçu Leporinus macrocephalus (Garavello \& Britski, 1988) machos e fêmeas. Revista Varia Scientia, Cascavel, v. 4, n. 8, p. 71-78, 2004.

SIPAÚBA-TAVARES, L. H. S. Limnologia aplicada à aquicultura. Jaboticabal: Funep, 1995. 72 p. 
